DOI https://doi.org/10.18551/rjoas.2018-04.37

\title{
LIQUID SOAP CHARACTERISTIC WITH THE ADDITION OF FISH BONE COLLAGEN
}

\author{
Nauli Asti Permata* \\ Biotechnology Fisheries and Marine, Airlangga University, Indonesia \\ Darmanto Yudhomenggolo Sastro, Susanto Eko, Lecturers \\ Fisheries and Marine Science, Diponegoro University, Indonesia \\ *E-mail: astiangelica@gmail.com
}

\begin{abstract}
Doublewhip Threadfin Bream (Nemipterus nematophorus) fish is one of the low-cost economical sea fish that can be utilized which is expected to increase its selling value. The utilization of Doublewhip threadfin bream fish can be done with the waste management of the bones in order to have a selling value. Based on the research, other than its skin, bone is also one of the collagen producers in the body of a fish that can be used to increase the amount of collagen in the human body and slowing the aging process caused by damage skin cells that exposed to free radical. Fish bones are also an alternative to the mammals bones such as cows and pigs as collagen production materials that have been damaged by certain diseases. The method used in this research was laboratory experimental using Completely Randomized Design (RAL) design. This research aims to analyze the characteristics of fish bone collagen that is applied to the liquid soap, which is done by physic and high. Based on the result of the test, the stability of foam is $84.90 \%$; viscosity 922.83 ; cPs; $\mathrm{pH} 10.77$ and free alkali $0.031 \%$ which meets the requirements of liquid quality based on SNI 06-4085-1996 so it is safe to apply on human skin.
\end{abstract}

\section{KEY WORDS}

Collagen, fish bone, doublewhip threadfin bream, liquid soap.

Doublewhip Threadfin Bream (Nemipterus nematophorus) is a fish that is easily found in tropical waters, especially Indonesia. They are found in tropical waters of the Indian and western Pacific Oceans. Most species are benthic carnivores, preying on smaller fishes, cephalopods, crustaceans and polychaetes; however, a few species eat plankton. The fish with low-cost economical usually exported in the form of fillets, causing a buildup of waste fishbone. The national fish bones waste production in 2006 at Snapper fish species reach 14039.28 tons, 727.72 tons for Doublewhip Threadfin Bream and Mackerel reach 38133.35 tons [1]. The large number of fish bones when not used optimally, this will result in environmental pollution. Fish bones as a waste can still be fully utilized to increase the selling value. This utilization can be done by obtaining collagen from the bone as an additive in cosmetic products or other medicines. Collagen itself has a good function in the human body, especially on the skin.

Collagen has a wide range of applications in leather and film industries, pharmaceutical, cosmetic and biomedical materials and food. Generally pig, cow skins and bones are the main sources of collagen isolation. However, the outbreak of mad cow disease has resulted in anxiety among users of cattle gelatin. Additionally, the collagen obtained from pig bones cannot be used, due to religious constraints. As a consequence, increasing attention has been paid to alternative collagen sources, especially fish skin and bone from seafood processing wastes. About $30 \%$ of these wastes consist of skin and bone, which are very rich in collagen. However, fish collagens have lower thermal stability than mammalian collagens because fish collagens contain lower imino acid contents than mammalian collagens. So far, skin and bone collagen from several fish species have been isolated and characterised [2]. The collagen temperature heating is $45^{\circ} \mathrm{C}$ to avoid collagen degradation to gelatine. 


\section{MATERIALS AND METHODS OF RESEARCH}

The main material used in this research is the fish bone Kurisi as well as some basic ingredients of making liquid soap. This sample is obtained from the processing industry in Central Java. While the main equipment which is used i.e. digital thermometer (TP3001), a beaker glass (PYREX), hot plate stirrer (Cimarec 2), stainless steel pot, vortex mixer (BOECO), pH meter (SCHOTT), analytical scales (OHAUS).

Manufacture of fish bone collagen in this study i.e., fish bone wash, degreasing for 30 minutes, draining under $32-40^{\circ} \mathrm{C}$, demineralization with $4 \% \mathrm{HCl}$ with $1: 6$ ratio for 4 days, $\mathrm{pH}$ neutralization after forming ossein, $32-40^{\circ} \mathrm{C}$ drying for 2 days, and blended afterwards.

Myristic acid, lauric acid, and stearic acid, are heated in a heat-resistant container until all are melted (group A). $\mathrm{KOH}$ is dissolved with akuades in a separate container and then put into section $A$, stirring until a perfect lathering reaction. Then along with stirring, successively inserted Texapon, CAB-30, and EDTA $2 \mathrm{Na}$. Furthermore, the aquades is added to the above mixture little by little and stir until homogeneous. Thereafter, propylene glycol, glycerin, and $\mathrm{KCl}$ were added while stirring. Dye, perfume, and collagen is added after the temperature of the mixture is not too hot. Next add the pearl concentrate, mix well and store in a sealed container.

Quality Test of Liquid Soap Collagen:

- $\mathrm{pH}$ : The electrode has been cleaned up and then dipped into a soap sample, $\mathrm{pH}$ value is read on the $\mathrm{pH}$ meter after the numbers are stable and recorded. The $\mathrm{pH}$ test was performed with a digital $\mathrm{pH}$ meter (SCHOTT).

- Free Alcali: Prepare a neutral alcohol with $100 \mathrm{ml}$ of ethanol, added with $0.5 \mathrm{ml}$ phenolftalein and cooled until the temperature reach $70^{\circ} \mathrm{C}$ and then neutralize with $0.1 \mathrm{~N} \mathrm{KOH}$-ethanol. Add $5 \mathrm{ml}$ of the sample to the neutral alcohol, and add the boiling stone. Then boil for 30 minutes. If the solution does not contain alkalis (not red colored), cooled until the temperature reach $70^{\circ} \mathrm{C}$ and titration with $0,1 \mathrm{~N} \mathrm{KOH}$-etanol until the color stands for 15 seconds. However, if the solution is alkaline (colored red) then the examined is not fatty acid but free alkali titration using $0,1 \mathrm{~N} \mathrm{HCL}$-etanol until red color disappear.

- Foam Stability: Aquades and liquid soap with a ratio of 9:1 inserted into the test tube. Spin test tube for 5 minutes using the vortex mixer (BOECO). After the spin, the height of the foam present in the test tube is calculated $(\mathrm{a} \mathrm{cm})$. The test tube allowed to stand for one hour, then count the remaining foam height in a test tube $(\mathrm{b} \mathrm{cm})$. Calculate the percentage of foam stability.

- Viscosity: The measurement is done by using Brookfield LV with number 4 spindles viscometer. Viscosity is measured by stirring at a speed of $30 \mathrm{rpm}$ with the correction factor of 200. The result are shown on the tool multiplied by the correction factor.

Data Analysis. The parametric test data obtained from the results of $\mathrm{pH}$ test, free alkali, foam stability, and viscosity of fish bone liquid soap collecting in this research, analyzed by Analysis of Variance (ANOVA), to determine the effect. The parametric test data were repeated three times each. If the results have been obtained that show the real difference, then continued with further test that is the test of Honestly Significant Difference. The followup test is used to determine which treatment is most significant in this research.

Similarly, the non parametric test obtained from hedonic test result of liquid soap fish bone collagen in this study, analyzed by Kruskal Wallis test using SPSS and conducted further Dunn's Multiple Comparison test. The follow-up test is used to determine which treatment is most significant in a study.

\section{RESULTS AND DISCUSSION}

Characteristics of liquid soap with different types of fish bone collagen treatments can be seen in Table 1. 
Table 1 - The Results of Liquid Soap Characteristics

\begin{tabular}{|c|c|c|c|c|c|}
\hline \multirow{3}{*}{ Type of analysis } & \multicolumn{4}{|c|}{ Collagen concentration (\%) } & \multirow{3}{*}{ St } \\
\hline & \multirow{2}{*}{0} & \multicolumn{3}{|c|}{0,2} & \\
\hline & & TB & $\mathrm{M}$ & $S$ & \\
\hline Hedonics $(n=30)$ & $5,10 \pm 0,37$ & $5,78 \pm 0,48$ & $5,04 \pm 0,43$ & $4,82 \pm 0,14$ & - \\
\hline $\mathrm{pH}$ & $10,11 \pm 0,19$ & $10,77 \pm 0,06$ & $10,94 \pm 0,02$ & $10,87 \pm 0,09$ & $6-11$ \\
\hline Free alkaline (\%) & $0,03 \pm 0,001$ & $0,031 \pm 0,001$ & $0,07 \pm 0,004$ & $0,06 \pm 0,001$ & Max. 0,1 \\
\hline Foam stability (\%) & $99,33 \pm 1,15$ & $84,90 \pm 0,85$ & $66,45 \pm 0,38$ & $84,57 \pm 1,40$ & $60 \%-100 \%$ \\
\hline Viscosity (cPs) & $852,33 \pm 0,28$ & $922,83 \pm 1,2$ & $962,33 \pm 2,75$ & $932,66 \pm 3,05$ & $400-4000$ \\
\hline
\end{tabular}

Notes:

- $\quad$ TB (Threadfin Bream), M (Mackerel), S (Snapper), St (Standart);

- $\quad$ Data were the average of three repetitive treatments \pm Standard Deviation;

- Data were compared to the use of Mackerel and Snapper fish collagen.

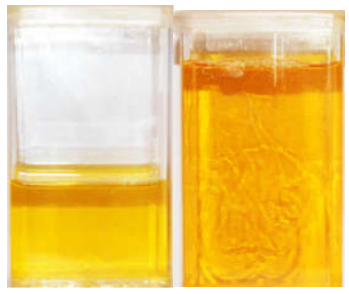

(a)

(b)

Figure 1 - Control (a), Soap with Doublewhip Threadfin Bream Fish Bone Collagen (b)

The lowest $\mathrm{pH}$ (10.77) was found in the addition of Threadfin Bream (Kurisi) fish bone collagen, meanwhile the addition of Mackerel fish collagen had the highest $\mathrm{pH}$ (10.94). The difference was influenced by $\mathrm{pH}$ level in fish bone collagen. The $\mathrm{pH}$ level of fish collagen is different because Mackerel bone is bigger and does not have many segments than Threadfin Bream and Snapper so it is easier to neutralize $\mathrm{pH}$ and leave no acid solution. The higher $\mathrm{pH}$ level of collagen makes the $\mathrm{pH}$ level of soap becomes more alkaline. The use of strong alkaline chemical such as $\mathrm{KOH}$ can increase soap's $\mathrm{pH}$ level. The making of collagen liquid soap in this study is in accordance with the quality standard [3]. It states that the ideal acid value of liquid soap ranges from 6 to 11 .

The result of ANOVA test showed that the different types of fish bone collagen treatments had a significant effect on collagen liquid soap, because $F_{\text {value }}(34.34)>F_{\text {table }}$ (0.05) (4.06). It proves that the different types of fish bone collagen in the making of collagen soap had a significant effect on the $\mathrm{pH}$ level.

Based on the table above, it can be seen that the lowest free alkaline was liquid soap without collagen addition $(0,030 \%)$. Then, the highest free alkaline was Mackerel bone collagen liquid soap $(0.070 \%)$. It showed that free alkaline level was directly proportional to $\mathrm{pH}$ level. The higher is the $\mathrm{pH}$ level, the higher is the free alkaline level. The stirring of liquid soap decreases alkaline level. It is because $\mathrm{KOH}$ reacts more perfectly and is bound to acids produced by coconut oil. A solution of 10-7 mol/liter (10-7 grams/liter) of proton is a neutral solution; meanwhile more than $10-7$ is an alkaline solution (base). Therefore, the higher is the $\mathrm{pH}$ level, the higher is the alkaline level [4]. According to the National Standardization Agency (1996), the maximum free alkaline level of liquid soap is $0.1 \%$.

The result of ANOVA test showed that the different types of fish bone collagen treatments had a significant effect on collagen liquid soap, because $F_{\text {value }}(258.08)>F_{\text {table }}$ (0.05) (4.06). It indicates that the different types of fish bone collagen in the making of collagen liquid soap had a significant effect on the free alkaline level.

It is known that Threadfin Bream bone collagen liquid soap had the highest foam stability value of $84.90 \%$. Meanwhile, Mackerel bone collagen liquid soap showed the lowest result of $66.45 \%$. The higher is the foam stability value, the higher is the foam quality produced by the liquid soap. Foam stability is highly influenced by particle size. The more 
and bigger is the particle size, the lower is the foam stability. The foam percentage above $(70 \%)$ can be categorized as good because it can still keep the bubbles from breaking.

The result of ANOVA test showed that the different types of fish bone collagen treatments had a significant effect on collagen liquid soap, because $F_{\text {value }}(518.84)>F_{\text {table }}$ (0.05) (4.06). It proves that the different types of fish bone collagen in the making of collagen liquid soap had a significant effect on the foam stability value.

The highest viscosity value was found in liquid soap with the addition of Mackerel bone collagen (962.33 cPs); meanwhile the lowest was found in liquid soap with the addition of Threadfin Bream bone collagen (922.83 cPs). Viscosity can be lowered by the increased water/soap ratio because viscosity is influenced by the water content of soap. The less water content of soap increases the viscosity, and vice versa. The higher the protein content, the higher the viscosity value. This shows that the amino acid chain is getting longer.

The result of ANOVA test showed that the different types of fish bone collagen treatments had a significant effect on collagen liquid soap, because $F_{\text {value }}(884.05)>F_{\text {table }}$ (0.05) (4.06). It indicates that the different types of fish bone collagen in the making of collagen liquid soap had a significant effect $(p<0.05)$ on the viscosity value.

\section{CONCLUSION}

The stability of foam on Threadfin Bream collagen soap is better than Mackerel and Snapper. This is because the fish bone collagen has a smaller particle size, so it is more easily soluble and does not interfere with the formation of foam produced by soap. Threadfin Bream bone collagen have a lower viscosity level than Mackerel bone collagen because the protein structure of mackerel fish is longer.

The viscosity and free alkaline of Threadfin Bream bone collagen liquid soap had a significant effect $(p<0.05)$ to Mackerel and Snapper collagen liquid soap. Then, the tests on $\mathrm{pH}$ level and foam stability showed that Threadfin Bream bone collagen liquid soap had no significant effect $(p>0.05)$ to Snapper collagen liquid soap, but it had a significant effect $(p<0.05)$ to Mackerel collagen liquid soap. The hedonic value of liquid soap with the addition of Threadfin Bream bone collagen had a significant effect $(p<0.05)$ to the liquid soap with the addition of Mackerel and Snapper bone collagen.

\section{REFERENCES}

1. Departemen Kelautan dan Perikanan. 2007. Statistik Kelautan.

2. Perikanan Tahun 2006. Departemen Kelautan dan Perikanan, Jakarta.

3. Kittiphattanabawon, P. et al "Characterisation of Acid-Soluble Collagen from Skin and Bone of Bigeye Snapper (Priacanthus tayenus)", Science Direct Food Chemistry, vol. 89, pp. 363-372, February 2005.

4. Badan Standardisasi Nasional. 1996. Standar Nasional Indonesia Tentang Sabun Mandi Cair. SNI 06-4085-1996. Jakarta.

5. Barnes, D, P J Bliss, B W Gould, H R Vallentine. 1983. Water and Wastewater Engineering Systems. Pitman: London. 